\title{
Impact of incessant kidnappings on the external relations: A case study of Nigeria
}

\author{
Yusuf Kamaludeen Ibrahim* | Abdullahi Ayoade Ahmad | Sani Shehu
}

Faculty of Law and International Relations, University Sultan Zainal Abidin, Terengganu, Malaysia.

*Corresponding Author Email: yusufkibrahim04@gmail.com

\begin{abstract}
Nigeria is a West African country, endowed with a rapidly growing population of over 206 million, with over 500 languages and 250 ethnic groups. It is Africa's most densely populated country and the world's largest black nation. The integration of these complex entities into a unified body has proved difficult since the country's 1914 amalgamation. The government is challenged with violence and military dictatorships, endemic corruption, and abject poverty that intensifies heinous crimes, including kidnapping. The menacing impact of the phenomenon ravaged throughout the country resulted in many lives lost and cripple the economy. Even though it is enshrined in the Nigerian 1999 Constitution, chapter 2, section 14(2b), that the protection of lives and property is the state's core responsibility. The study aims to uncover the effects of kidnapping on Nigeria's foreign relations. The study adopted a qualitative method, using secondary sources and world-system theory. The study found that failure to address the root causes of kidnapping is why kidnapping prevails in the country. Consequently, the study developed some measures and panacea to the country's deteriorated and incessant insecurity challenges. Noticeably, heinous crimes will be eradicated and replaced with economic wellbeing and strengthen the country's external relations.
\end{abstract} Article History

Received:

June 11, 2020

Last Revised:

April 14, 2021

Accepted:

April 15, 2021

Published:

June 3, 2021

Keywords: Nigerian kidnapping, Nigeria's security challenges, Nigeria's external relations, effects of kidnapping, proposed panacea for Nigeria.

How to Cite: Ibrahim, Y. K., Ahmad, A. A., \& Shehu, S. (2021). Impact of incessant kidnappings on the external relations: A case study of Nigeria. Liberal Arts and Social Sciences International Journal (LASSIJ), 5(1), 212-227. https://doi.org/10.47264/idea.lassij/5.1.15

Publisher's Note: IDEA PUBLISHERS (IDEA Journals Group) stands neutral with regard to the jurisdictional claims in the published maps and the institutional affiliations.

Copyright: (C) 2021 The Author(s), published by IDEA PUBLISHERS (IDEA Journals Group). This is an Open Access article published under the Creative Commons Attribution-NonCommercial 4.0 International License (http://creativecommons.org/licenses/by-nc/4.0/) 


\section{Introduction}

The global phenomenon of kidnapping is as early as human history, perpetrated with certain scenarios and differences. Kidnapping is the illegal abduction of an individual or group of people for a ransom or other criminal act. In the context of Nigeria, kidnapping was rare prior to the 1990s, which were not recorded on the Crime trends on Eighth United Nations Survey on Criminal Justice System Operation conducted in 2002 through United Nations Office on Crime and Drugs (Obarisiagbon \& Aderinto, 2018). The intensified wave of kidnapping emanated in Nigeria in February of 2006 via abduction of foreign employees working for the multinational oil companies in the region of Niger Delta. The kidnaps were portrayed as a message to the Nigerian government and the international community over the region's alleged exploitation and marginalization (Akpan, 2010). Ever since, the menacing impacts absorb the core and peripheral of the Nigerian criminal system, affecting the young, aged, locals, and foreigners for a ransom or other unlawful activity. The study aims to elaborate on the impacts of kidnapping on Nigerian external relations, its effects on the country`s image in the international community, impediment of tourism investment, and its deterrence of Foreign Direct Investment (FDI). Provided some panaceas and measures to tackle security threat in the country so that our neighbouring countries and the international community can view our efforts in fighting vicious crimes such as kidnapping in the country, in order to create a safe and transparent environment for foreign direct investment, promote economic growth, resuscitate development and strengthen a bilateral and multilateral relationship with neighbouring nation and other countries of the world (Ibrahim et al., 2020).

Table-1: Recorded trends of kidnapping in Nigeria

\begin{tabular}{|c|c|c|c|}
\hline Year & Quarter & Value & \% Change \\
\hline 2018 & Q4 & 40.00 & $37.93 \%$ \\
\hline 2018 & Q3 & 29.00 & $70.59 \%$ \\
\hline 2018 & Q2 & 17.00 & $183.33 \%$ \\
\hline 2018 & Q1 & 6.00 & $-90.77 \%$ \\
\hline 2017 & Q4 & 65.00 & $66.67 \%$ \\
\hline 2017 & Q3 & 39.00 & $25.81 \%$ \\
\hline 2017 & Q2 & 31.00 & $82.35 \%$ \\
\hline 2017 & Q1 & 17.00 & $-41.38 \%$ \\
\hline 2016 & Q4 & 29.00 & $14.37 \%$ \\
\hline
\end{tabular}

Source: Knoema (2018) (UN Office on drugs and crime).

The catastrophe of the kidnapping phenomenon has devastated the nooks and crannies of the Nigerian state. Based on the report from the UN office on crimes and drugs, the trends of incessant abductions revealed that the menacing kidnaps in Nigeria in the fourth quarter of 2016 were rate at 29.00 value and changed at an average $14.37 \%$, it intensified to 65.00 in the fourth quarter of 2017 and changed at $66.67 \%$, it also escalated to 40.00 in the fourth quarter of 2018 and change at an average rate of $37.93 \%$ (Knoema, 2018). The menace's intensification has bedevilled the nation, recruiting idle-minded individuals venturing viciously into the act. The country has been perceived as the hotbed and volatile of catastrophic heinous crimes in West Africa, which has ruined its reputation abroad. Notably, in 2006 the country was ranked $11^{\text {th }}$ among 12 high kidnapping nations worldwide (Christi, 2008). Relatively, the nation evolved second in Africa, After South Africa (Adagbabiri \& Okolie, 2018). Based on the recent report by crime index mid-year (2018), Nigeria was $14^{\text {th }}$ in the world and $3^{\text {rd }}$ in Africa. The 
menace's luckier victims were often released after brutal torture and compensation of bountiful ransom, while the unfortunate victims often died in captivity.

Furthermore, the impact of the menace has caused capital flight because many investors are withdrawing their interest and investment in the country, which resulted in an economic meltdown. The menace has degraded the county from its $6^{\text {th }}$ position as the leading oilexporting country in the world to $7^{\text {th }}$ position in 2019. Based on the latest INF; World Economic Outlook (WEO), the Nigerian GDP in 2011 is 414.10 billion USD, $\$ 568.50$ in 2014, but regrettably dropped to $\$ 376.36$ in the year 2017 and $\$ 398.19$ billion in the year 2018 due to intensified kidnap incidences (Knoema, 2019). Obviously, insecurity is the major tool manifesting to deter investors from losing interest in the country and withdrawing their investment to a safer/stable environment in Africa. For instance, the intensification of militancy in the oil region of Niger Delta incurred a decline of almost $\$ 5.85$ billion in the year 2006 from the $\$ 13.96$ billion in the year 2005 (Nwozar, 2010). Relatively, by the first quarter of 2009, Royal Dutch shell discovered the downfall of their production from 1million BPD to about $250,000 \mathrm{bpd}$ due to disruptions and kidnapping of foreign employees devastated the multinational company's output and crippled the Nigerian Economy (Uma \& Ikpe, 2016).

\section{Theoretical underpinnings}

The internationalization of kidnapping in Nigeria has implications for the country's reputation in the international community. In this regard, the concept of the global system includes the idea that the world goes beyond the mere sum of the part and that its world politics exceeds the sum of the individual interaction between these parts; the framework for this study will be guided by world-system theory pioneered by (Wallerstein, 1974). The theory stated that all international system elements are interrelated and thus in a dynamic relationship with each other. The global system is an arena for global politics with many contributors, and the most important are nation-states. These interactions between states are based on specific policies formulated by different political entities (states). These plans are referred to as foreign policies. They are the goals and objectives that a state sets to achieve beyond its territorial borders and are built internally with transparency, commitment, and accountability for international manner. Foreign policy decision-making tends to focus more on the national interest of the state. Hence, countries try to influence the behaviour of other countries in the required direction. Such conduct must first be based on peace and security, respect for the rule of law and human rights, as well as social and economic development (Etemike, 2012).

Moreover, it is also pertinent to note that such middle-scale issues or common interest in which class interest tends to have a decisive influence on policymaking and those external policies tend to invest in the context of ideological justification can also be considered complementary. Or an extension of domestic politics (Utete, 1965: 44). The foreign policy of the late President Umar Musa Yar`adua's administration in 2007 was hinged on citizen diplomacy, while his predecessor, former President Goodluck Jonathan's administration in 2011 adopted a transformation agenda in line with his domestic political orientations, including attracting foreign investment. The current administration of President Buhari, who took office in 2015, has launched the foreign policy agenda of his administration regarding cooperation with global entities to combat the threat to national security, such as Boko Haram and kidnapping, among others, reviving the local economy to attract foreign direct investment, and partnering with global cooperation in fighting corruption, as well as military and diplomatic steps to eliminate national security threats in the country (Bello et al., 2017). 
Above all, every foreign policy relationship is guided by certain factors such as: (A) societal structure and power, (b) circumstantial factors and emergencies, including economic and social crisis, elections, violence, and coups, among others, (c) the state system, including governmental decision-making mechanism (d) leadership that It indicates how incumbents and decision-makers use state power (Brucan, 1978: 3). In this context, circumstantial and emergency factors will be contextualized, including the Nigerian economic and social crisis, coups d'état, the ensuing civil war, violence, ethnic clashes, and political and civil unrest paving the way for a security threat to deteriorate in the country. Kidnapping is not different from these factors, as it has been terrorizing the country since the amalgamation, constituting other organized crimes, and is profitably consumed by Nigerian criminal gangs, as a result of the country's flawed institutions such as high unemployment rates, rampant corruption, and others (Etemike, 2012; Shelley \& Meher, 2008). In the context of this study, when discussing the threat to national security and heinous crimes, the above factors became relevant, and the kidnapping in the Niger Delta and other parts of the country as an internal issue provoked specific foreign reactions. Wallerstein argued that to understand the behaviour, traits, or function of a single element (unit) in the international system, one must understand its position within the whole (Hobden \& Jones, 1997: 130). This function indicates the way manner in which each entity (state) operates; The three arms of the government in Nigeria are mired in a national security threat that has become vulnerable to internal shocks, such as terrorism, militancy, banditry, and kidnapping, among other security threats, persisted due to lack of a rigorous, practical and broader mechanism of governing the citizenry in the country.

According to Wallerstein, the international system is a central concept and has been seen as a container that occupies the global system's territorial space. The problem that occurred in one of the units (an entity or states) will involve, in one way or another, the remaining contributors to the global economy. In the context of Nigeria in this situation, the international system perspective, by contrast, suggests that viable relations take place in a state or entity in which there is a continuous division of labour and seeks to empirically reveal whether or not that entity or state politically, culturally and economically integrated, theoretically what are the challenges of the non-existence or existence of this unity (Wallerstein, 1976). Nigeria is a diverse entity with many mineral resources but with poor governance, ethnic prejudice, inequality, a weak judiciary, and a corrupt educational and economic system. Despite all the resources available in the country, Nigeria, according to Transparency International, ranked 142nd out of 163 countries surveyed, Corruption Perception Report in 2006. Also, in 2018, the country ranked 146th out of 180 countries surveyed; it is also ranked $151^{\text {st }}$ in the high unemployment rate in the world and $55^{\text {th }}$ in the ranking of the poorest countries in the world during 2020.

Moreover, Anifowose (1982) also stated that lone groups often indulge in kidnapping and other heinous crimes to display and highlight the unbearable burden on their necks, as well as social injustice, marginalization, ethnic prejudice, and mismanagement, among other things, which pushed these groups into grabbing arms to perpetrate vicious acts. Mallett and Slater (2012) argued that a fragile state often dwells in conflicts and crises, weak to domestic conflict and vulnerable to internal shocks. As in the Nigerian situation, countries that suffer from challenges such as social and regional imbalance, insecurity, and insufficient basic facilities fall into the category of a failed state. Senge et al. (2008) claimed that countries facing specific challenges such as mismanagement, political turmoil, poor infrastructure, unemployment, poverty, and slow economic growth are said to be failed states. 
The theory asserted that less attention had been paid to the environmental vision in the way the state functions, and much progress has also been made in positioning the state's analysis in an international environment such as social, political, and economic relations within a single community and territorial boundaries within a particular state (Hobden, 1999). As such, the economic, social, and political relations of the Nigerian state and its society have become warring since its independence in 1960; The nation has been in a state of a coup, civil war, political turmoil, social vices and organized crime, terrorism, and heinous crimes, among others, for decades. The threat of kidnapping in Nigeria, which began in the Niger Delta, with the abduction of citizens and foreigners working in the multinational cooperation companies, has affected the country and its image in the international community. It produced 27 thousand barrels in 2006 and decreased to two thousand barrels in 2018 and 1346 barrels in 2020, respectively (US Department of Energy). As such, Nigeria is a member of the Organization of the Petroleum Exporting Countries (OPEC), Nigeria, Egypt, Kenya, and South Africa (NEKS), among others, are the countries that have endowed enormous mineral resources and have contributed significantly to the international. The production of these minerals, which due to kidnapping, affected its massive contribution to such organizations and the international community, as well as deterred foreign investors from investing in the country (Etemike, 2012).

\section{Research methodology}

The study employed a qualitative approach, adopted secondary/library sources on the intensifying impacts of Nigerian kidnapping phenomena on the country`s reputation in the international community, including books, media reports, previous literature, journal articles, and newspapers, among others. The study adopted world-system theory to elaborate the impacts of kidnapping on Nigerian external relations, also to illustrate the negligence and reluctance of the Nigerian government to re-engineer the faulty and corrupt institution in the country, as well as address the root causes of the heinous crimes perpetrating all over the country. Ensuring the security of lives and property is not only a moral issue but a key priority of a nation-state. The adaptation of this method was perceived as a strategic route in reaching first-hand information about deteriorated heinous crimes as well as grasping the magnitude of high profile kidnaps in Nigeria in order to address the gap and stem the tide of the menace for future will be perpetrators, resuscitate production, strengthen Nigerian external relations and revive its image in the international community for the wellbeing of the entire society.

\section{The belligerence of kidnapping to Nigerian foreign policy: A discussion}

Generally, foreign policy is the extension lead of internal or domestic policy, designing to enhance the state's possibility of delivering certain programs concerning National interest, set to address certain issues to pursue an objective involving action towards foreign entities. Domestic and external environments are two vital factors determining each country's foreign policy (Ivanovic, 2008). Evidently, the deteriorative kidnaps of foreigners and citizens flung the Nigerian foreign relations in jeopardy and tarnished her image in the international community. The two broad grounds that determined each country`s foreign relations are both internal and external environment, the Umar Musa Yar`Adua/Goodluck Jonathan 2007 to 2015 foreign policy objective hinged on transparency and strengthening ties with foreign countries and the policy of uniting citizen's diplomacy.

The current administration of Muhammad Buhari that resumed office in 2015 was shaped on the foreign policy of strengthening Nigerian relations with neighbouring countries and major 
powers such as the US and China, among others, in order to harmonize together, forged ahead, and come up with strategic measure in fighting security threat in the country and the rest west African Sahel. The administration of Buhari had prioritized three significant points, which are; to restore and energized the economy, eradicate corruption, and tackling terrorism, insecurity, and kidnapping (Bello et al., 2017). Regrettably, intensified heinous crimes ravaged such efforts and robbed the country of the benefits brought by such opportunities. Therefore, investment is a key factor in developing and boosting every country's economic growth. Relatively, countries that are unable to save or lack accumulation to be channelled from consumption to investment often attract foreign direct investment to boost their economy and create job opportunities (Adeniran, 1983).

Based on WTTC (2012), tourism investors often withdraw their interest and investment from volatile environments. The catastrophe of kidnapping has massively affected the Nigerian tourism sector; the country`s tourism sector contributes massively to the Nigerian economic sector due to the tax it generates through the Nigerian internal generating revenue. Unfortunately, some unforeseen consequences impede the country's tourism activity, including terrorism, poor electricity, militancy, armed robbery, banditry, and kidnapping for ransom. Tourists are no longer interested in Nigeria due to the fear of being kidnapping victims and other vicious acts perpetrating in the country. According to Danlami (2012), the priorities determining each country`s tourism attraction are the nation's safety and security conditions.

Table-2: Nigerian foreign direct investment inflow

\begin{tabular}{|c|c|c|}
\hline Date & Value & \% Change \\
\hline 2018 & $1,997,485,165$ & $-42.98 \%$ \\
\hline 2017 & $3,502,999,131$ & $-21.26 \%$ \\
\hline 2016 & $4,448,732,917$ & $45.19 \%$ \\
\hline 2015 & $3,064,168,904$ & $-34.72 \%$ \\
\hline 2014 & $4,693,828,632$ & $-15.62 \%$ \\
\hline 2013 & $5,562,873,606$ & $-21.32 \%$ \\
\hline
\end{tabular}

Source: Knoema, world data atlas (2018).

Based on the world data atlas report 2018, the catastrophe of incessant kidnaps in Nigeria impacted the country's Foreign Direct Investment, which led to the crippling of the Nigerian economy. Nigerian economy shrinks from \$5,567 in 2013 and \$4,693 in 2016 that change at $21.32 \%$ and $45.19 \%$ respectively, becomes leaner to $\$ 3,502$ in 2017 and $\$ 1,997$ and change at $-29.26 \%$ and $-42.98 \%$ respectively (Knoema, 2018). Nwogwugwu et al. (2012) scrutinizes that there is a positive correlation between multinational or foreign direct investment and Nigeria's Economic growth, "1\% increase in multinational direct investments will source as up to $80 \%$ growth in the GDP. Furthermore, (Ibrahim \& Ahmad, 2020) speculate that the intensification of heinous crime in Nigeria had been echoed globally, led to the impalement of visa ban restriction to Nigeria by the United States, and cautiously warned other countries concerning the dangers bound on traveling to Nigeria. As such, the jeopardy hit the tourism sector, causing a massive decrease in its activities and cripple Nigerian Economy (Olaniyi, 2020). Also, international organizations such as UNICEF, DFID, USAID, and others, coherently withdrew from the trouble spots of the country, that resulted in inaccessible adequate health facilities the citizens are benefiting from in many ways (Ojukwu, 2011). As such, it ruined the Nigerian reputation in the international community, caused economic decay and poor infrastructure as well as displaying the sign of state fragility, which includes the failure of the state to carried- 
out the 'basic needs' of statehood to its citizens, such as guaranteeing absolute human security and capable engine of growth via the political process (Mcloughlin, 2012:9).

\subsection{Implications of kidnapping to Nigerian image in international community}

According to Wallerstein (1974), the world-system approach stressed that all global system elements are interrelated and are accordingly in a dynamic relationship. To understand the behaviour, attributes, or function of a single unit (component), one must understand its situation within the whole (Hobden \& Jones, 1997: 130). Under this perspective, Nigeria's internalization comprises its respect to human rights, political and socioeconomic well-being, and institutional stance towards democracy. The foreign policy of the late President Umar Musa Yar`adua in 2007 was based on citizen diplomacy, while the administration of his predecessor, former President Goodluck Jonathan in 2011 adopted a transformation agenda in line with his domestic political orientations, which included attracting foreigners. Investment. The current administration of President Buhari, who took office in 2015, has directed the foreign policy agenda of his administration to cooperate with global entities to combat the threat to national security, such as Boko Haram and kidnapping, among others, to revive the domestic economy to attract foreign direct investment, and to partner with global cooperation. In the fight against corruption, as well as military and diplomatic steps to eliminate national security threats in the country (Bello et al., 2017). The administration's foreign policy goals were limited to eliminating security threats and attracting foreign investment.

The threat of kidnapping in Nigeria, which began in the Niger Delta, with the abduction of citizens and foreigners working in multinational companies, has affected the country and its image in the international community. The Nigerian government adopted an amnesty approach in the past and subsequent kidnapping crises in the Niger Delta. This approach was a debatable strategy, but it yielded some positive results in the Niger Delta, which decreased crime and kidnapping in the region. The Niger Delta region produced 27 thousand barrels in 2006, but it declined to 2 thousand barrels in 2018 and 1,346 barrels in 2020, respectively, due to kidnappings and other dastardly acts in the region (the US Department of Energy). As such, Nigeria is a member of the Organization of the Petroleum Exporting Countries (OPEC), Nigeria, Egypt, Kenya, and South Africa (NEKS), among others, as the countries with enormous mineral resources and have contributed significantly to the international production of these minerals, which have affected the outcome of its vast contribution to such organizations and the international community, as well as deterring foreign investors from investing in the country. According to the New Partnership for Africa's Development (NEPAD), Nigeria presents an incredible paradox for a mega-rich nation, both actual and potential term; unfortunately, it is home to the third-largest segment of the world's poor. Despite Nigeria's huge annual revenues from oil wells, it has failed to provide basic amenities to its people (NEPAD 2008: 33). Moreover, it has also affected agricultural production in states such as Zamfara, Katsina, Kaduna, Taraba, Adamawa, and Benue, among others, which have been indicated as troubled areas of the country. Food security and other businesses have been greatly affected, and kidnapping has become a constraining factor for farmers to produce food for the country and neighbouring countries such as Chad, Niger, and Cameroon, who share regional borders and conduct commercial activities with these unstable states.

The families and relatives of the abducted victims in Nigeria are anxiously waiting for news of their kidnapped daughters and sons from the kidnappers. The mass kidnapping erupted on May 14, 2014, when the Boko Haram insurgency abducted more than 276 Chibok school girls in 
Borno. Also, on February 19, 2018, Boko Haram kidnapped more than 100 girls at Dabchi School from their school in Yobe State. On December 11, 2020, bandits kidnapped more than 344 students from Kankara and 80 students on the same day, both of them in the western state of Katsina. The perpetrators also stepped forward and kidnapped 42 schoolboys in Kagara on February 16, 2021, in Niger state. It keeps happening so much that on February 25, 2021, they also kidnapped more than 300 schoolgirls in Gangbei Zamfara state. On March 12, 2021, kidnappers abducted more than 39 students from the Federal Forestry Department of Mando Kaduna State. Regarding the mass kidnapping in the country, there was strong condemnation from the international community for the inhumane act perpetrating in the country.

UN Secretary-General António Guterres condemned the threat and called for the "immediate and unconditional release" of the detainees, stressing that the ongoing attacks on schools are a flagrant violation of human rights. And the Right of Children (Mansur, 2021). The ease of penetration of Nigerian borders has also given rise to an unjustified influx of migrants from neighbouring countries such as the Republic of Benin, Chad, and the Republic of Niger (Adeola \& Oluyemi, 2012). These migrants are often among the perpetrators of kidnappings in the country. Some world leaders have stressed the importance of Nigeria's security situation and its consequences, in word and deed, and encouraging the Nigerian government to prepare for the challenge. For example, former Ghanaian President John Kufuor stated that the curse of development in Nigeria is insecurity (Kufuor, 2012). He noted that Nigeria's insecurity costs Nigeria its leadership dominance in Africa in terms of social and economic development. As a result, it is unable to claim its rightful position as the "giant of Africa" those other African countries can benefit from or copy as a role model, and that "if there is no security, there is no freedom, no essence in life and society returns to the law of the jungle." It defeats the basic humanitarian goal of state formation (Kufuor, 2012).

To highlight the nexus between Nigeria`s development and its security situation, the United States, via its ambassador to Nigeria Eunice Reddick, stressed that Nigeria's national security threat is the main reason obstructing progressive efforts in the country and added that "security is vital for the development of the country." It is noted that the Nigerian incessant security threats are undermining the country's economic prospects. Therefore, there's a need for partnership in counterterrorism and insecurity in Nigeria, and it is inevitable because peace and security are vital to the development, and the national structural and transformation agenda of the current Nigerian administration may not be achieved if instability keeps perpetrating in the country (Ifeoma et al., 2015). Furthermore, in the previous years, violence consumed the country's north-western region due to ongoing abductions carried out by faction locally termed "Bandits." The sect is not an internationally recognized terrorist group capable of capturing the global media quickly. These crime targets are mostly local's communities, murdered and abducted as many as possible for ransom. According to the US Department of Defence, Philip Nathan Walton, a US citizen, was kidnapped on his farm in Masalata in southern Niger. The perpetrators demanded a ransom for the victim's father, and the US Department of Defence confirmed that the operation took place in northern Nigeria. "No American soldier was injured during the operation." The accident happened two months after the ISIS-linked faction killed six French aid workers and their guide in the Republic of Niger while visiting a wildlife park in the east of the capital.

The menace also happened in Yemen, where an Iranian-backed militant kidnapped US citizens. The US government negotiated their release in exchange for the return of about 250 Omani Houthi rebels (Tucker, 2020). Meanwhile, in Kombo northwest Cameroon, one of the country's 
English-speaking regions, 12 teachers were kidnapped with several students on November 6, 2020. One teacher and students were later released, while the remaining 11 teachers and a student were detained. To pay a ransom for their freedom. The kidnapping took place ten days after seven students were shot dead by armed separatists in their classrooms in Kumba. United Nations Secretary-General António Guterres expressed his "shock" at the "horrific attack" against innocent children. According to the Norwegian Refugee Council and Human Rights Watch 2020, the crises of the past three years in the English-speaking region have killed more than 3,000 people and displaced more than 730,000 civilians (Kum \& Forku, 2020). According to the OSAC 2020 report, kidnapping is no different in Chad; Kidnapping of Westerners remained a concern in Chad after the French emigrant's abduction in 2017. Ransom-paying kidnappings are spread along Chad's borders with the Central African Republic and Cameroon. It also tends to involve the local community and expanded across its Nigerian border. The US State Department has assessed Chad and its adjacent border as a highly volatile hijacking site in which disturbing extremist organizations (such as ISIS in West Africa, Boko Haram, Al Qaeda, and ISIS in Libya, among other associated groups) could easily infiltrate the border and target. Expatriates, local security personnel, and civilians in the Sahel and Lake Chad Basin. The threat resulted in the kidnapping and displacement of thousands of Chadians at the hands of the rebels across the Libyan border.

However, by the same token, the Nigerian government appears to have very little or no presence in most parts of the Northwest Territory outside its state capital; It has become very easy for non-state actors to penetrate the vast rural areas of the region. To make matters worse, the nearby national territorial borders in the provinces are porous and have been a conduit for smuggling weapons, drugs, and even people for many years. Combined with the high rate of poverty and unemployment, these factors fuelled and perpetuated the apparent train of kidnapping and other security threats in the country. According to Mortala Abdullah, Conflict, Climate and Security Reporter at Humangle-News, "The disaster of insecurity in the region has also paved the way for jihadist groups in their favour." "There was intelligence information that Boko Haram groups were trying to expand their territories from the Lake Chad region, while the active factions in neighbouring countries such as Burkina Faso, Mali, and the Republic of Niger were operating near the region (Amaza, 2020).

Moreover, one of the main direct factors driving insecurity in Nigeria is the ease with which the country's borders are penetrated, as individual movements are largely untraceable. Penetrating Nigeria's borders has profound security implications for the country. Due to porous borders as well as a weak security system, weapons are quickly coming into Nigeria from other countries. The proliferation and availability of small arms and light weapons have enabled armed groups and criminal groups to easily access firearms. It is estimated that Nigeria hosts more than 70 percent of the approximately 8 million illegal weapons in West Africa (Hazen \& Horner, 2007; Ibrahim et al., 2020)

\subsection{The challenges of kidnapping to Nigerian foreign direct investment}

Nigeria is part of NEKS countries, an acronym for Nigeria, Egypt, Kenya, and South Africa. Analyst describes them as the African countries with the vast available market for foreign direct investment during independence and post-independence. Nigeria was resonated as the preferable secured country in the West African sub-region due to its productive economic growth and leadership style in the Economic Community of West African States (ECOWAS) (Felix \& Okumoko, 2014). Nigeria is the global most populous African country and top oil and 
gas producer in Africa's continent. For quite some time, Nigeria has been challenged with various security threats since the foundation of its democracy in 1999. The government's reluctance to prioritized security in the country posed a severe threat to Nigeria`s unity and continued survival as a sovereign state (Badiora, 2015). According to (Nwogwugwu et al., 2012), the militants' way of operation, such as kidnapping and hostage-taking of over 200 expats as victims for ransom, worth hundreds of thousand dollars (Oriakhi \& Osemwengie, 2012). Also, shutting and blustering down oil and facilities, illegal oil bunkering estimated at over 80,000 and 300,000 bbl/day, has directly impacted Nigeria's economic development. According to a report by UNCTAD 2006, Nigeria is ranked $40^{\text {th }}$ most productive economy for foreign direct investment, but unfortunately, the FDI dropped cruel due to the weak performance of the Nigerian government to tackle security threat such as kidnapping which emanated by armed groups such as the Movement for the Survival of the Ijaw Ethnic Nationality (MOSEIN) and Movement for the Emancipation Niger Delta (MEND), among others in the oil region and deteriorated to the entire country.

Furthermore, such a group's illicit activities covering the kidnapping of foreigners working for oil companies in the region have brought instability to the country's wellbeing and oil production. It lurches the entire Nigerian economy because it affects the influx of foreign direct investment that supports the country's economy's development and growth. The menace intensified in 2009, despite the insertion of an amnesty program in the region, which impeded FDI as a result of oil bunkering and kidnapping that terrorized the country (Nwogwugwu et al., 2012). The foreign investors became frustrated and started diverting their investment to other safer environments in Africa, such as Angola, which makes Angola almost the highest crude oil producer in Africa.

Evidently, the illegal and brutal actions of the Niger Delta militants in the region brought about distress and frustration to the oil companies such as Royal Dutch Shell to look for a more stable and productive environment to secure their investment. The oil companies discovered the declining production from 1 million barrels per day (BPD) to about 250,000 BPD. Such illicit acts lurch the economy of Nigeria into deep decay (Alaibe, 2010). According to a United Nations report, $\$ 5.85$ billion dissolve in 2006 in the petroleum sector, from $\$ 13.96$ billion in 2005 due to incessant kidnaps in the region (Nwozar, 2010). Foreign Direct Investment helps in promoting and developing the economy of a host country in multiple ways, including growth in the actual output, standardized investment in the production of tangle goods, extension and generating business via motivation of the employees, raising of wages, and replacement of shrinking market sector, sustenance of external partners by the parent company with the provision of suitable materials and human resources, absence of such jeopardized host nations ability to import and guaranteed resourceful distribution of manufactured goods among others (Bakare, 2010).

Moreover, FDI has indeed positively supported the Nigerian economic growth and development (Asiedu, 2006; Akinlo, 2004). According to Bakare (2010), there is a significant positive nexus between multination direct investment and the economic growth of Nigeria, " $1 \%$ increase in FDI will source as much as $80 \%$ Gross Domestic Product (GDP) growth." An ominous sign that Nigeria is becoming disruptive in international investment. In a conductive survey for best attractive countries for FDI inducement, Nigeria was ranked the 40th best attractive economy for FDI (UNCTAD, 2007), making the country $4^{\text {th }}$ position in Africa, After Egypt, South Africa, and Morocco. 


\subsection{The effects of kidnapping on the tourism sector in Nigeria}

The tourism sector added immensely to every country`s economy; the sector produces $4.4 \%$ of total GDP and enormously contributed to the general economic growth through the provision of infrastructures such as roads, sewage treatment, telephone, disposal, and recycling, as well as pipe and treated water (WTO, 1999). According to WTTC (2010) estimation, it was revealed that in 2002, tourism, travel, and other related activities inserted $11 \%$ into the global GDP, ascend to $12 \%$ by 2010. In 2018 alone, it contributed $\$ 8,810.96$, and in 2019 it injected over 9,258 billion dollars (Statista, 2020). It also promotes and strengthens bilateral, multilateral, and sub-regional collaboration between the countries and states.

Tourism in Nigeria focused majorly on cultural events because of the country`s ample number of ethnic groups, savannah, waterfalls, rainforest, and other natural attractions (Akwara et al., 2014). Recently, the country`s federal and state government made an impact on the tourism development in Nigeria by synergizing with the private sector in exclusive resorts of global standard in a tourist attraction. Unfortunately, some significant factors are set to impede tourism development efforts in the country, such as the deplorable roads condition, insufficient electricity supply, religious intolerance, and militancy and kidnapping. Furthermore, Danlami, (2012) described that safety and security are the essential elements determining a country's tourism and travel attraction. Based on WTTC's (2012) report, tourism and tourist investors are being deterred from traveling and investing in insecure nations; countries such as Nigeria are in this category of countries where insecurity is significantly impeding tourism growth and development. Nigeria has been recognized as a volatile state due to high profile crimes and vices, such as kidnapping for ransom, hotels providing shelter to criminals, tourist sites patronized by drug addicts, muggers, prevailing political, and ethnic disturbances or clashes inhibited tourism impact to growth in Nigeria (Ajibola, 2016).

Furthermore, according to Pizam \& Mansfeld (1996) and Pitts (1996), the implications of heinous crimes and social vices such as kidnapping, political unrest, and others on the tourism industry are a major threat to the tourism sector and the economic growth of the country. Also, Aziz (2001) made a comparison of peaceful travels amongst nations as diplomatic relations to appreciate and admire the nature of their coexisting relationships, added that tourists might be single targeted for vicious attacks because they are being perceived as "soft targets" and emissaries of their home country. When tourists get kidnapped, the condition becomes exaggerated by media and obscure into a critical issue of international attention. For instance, four tourists were abducted on 21 April 2019; one among them, that has been murdered is a British aid worker that visited Kajuru castle resort in Kaduna state; the victim has been recognized by the British high commission as Faye Mooney, and she's a staff in a nongovernmental organization in Nigeria called Mercy Corps, the British embassy unclosed that "They are engaging with the government of Nigeria in investigating the devious act" (Muhammad, 2019). Regrettably, the victim's home country involvement and other nations in such a complex situation deteriorated, pressured, and tarnished the host countries image in the international community (Richter, 1983).

Moreover, Ritcher also acclaims that tourism tour and style portrayed political culture, class behaviour, and ideological value of both tourist and their countries of origin. Any mistreatment or harm to a tourist can negatively raise tension from his home country, and as a result of the massive revenue, the tourism sector injects into the economy, abducting a tourist can become an illegal channel of acquiring political advantages over political authorities (Richter \& Waugh 
Jr, 1986). Additionally, vices such as kidnapping, terrorism, political instability, and regional tourism restrict tourism (Enders et al., 1992). Also, tourists and nationality experiences determined tourist attraction towards a specific country (Akwara et al., 2014).

\subsection{Proposed panacea for heinous crimes in Nigeria}

The study scrutinizes the intensified and prevalence of heinous crimes throughout the country with regard to kidnapping and comes up with strategic panaceas and palliatives such as the implementation of synergized security and community policing approach, series of employment and empowerment programs, public awareness, and eradication of fire-arms and compulsory sim-cards registration, to quench the heated trends of vicious act afflicting the peace and prosperity of the Nigerian society and to deter or change the perspective of the future will-be perpetrators willing to plunge or venture into vicious acts and other social vices.

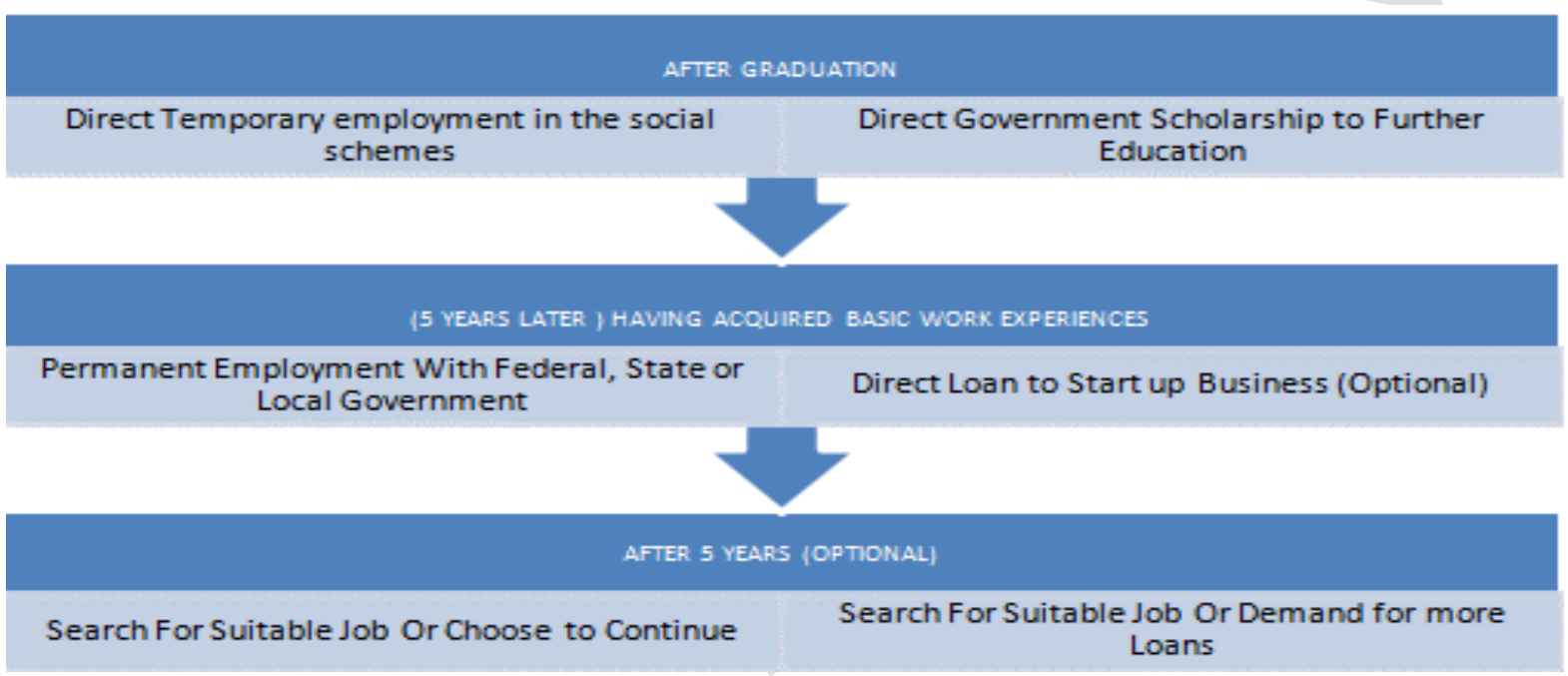

It reveals how the Nigerian citizens, especially the youths, could be guided to avoid remaining idle and turning to "the devil's workshop." After graduation, the sequence showcased that the Nigerian government should provide temporary employment or provide them with scholarships to further their education. After five years, the government should employ them with permanent appointments/offered them some loans to start up a business. Relatively, after five years, they should be offered a chance to continue with their existing jobs or search for another suitable employment, as well as those under loans should be given an opportunity to demand more loans in order to continue running their businesses. This study suggests that by adopting this strategic sequence, kidnapping will indeed be eliminated in the country.

Moreover, the study also recommends the community policing strategy, which has a high prospect of ensuring Nigerian society's safety and security. It will go a long way in tackling and resolving insecurity issues, including kidnapping in the country, through proactive surveillance and assessment of all that goes on in the community. Thereby, it will definitely reduce incessant crimes perpetrating in the community, and first-hand suspicions and information will be delivered to the security agencies to prevent the crime's occurrence and serves as crime control rather than prevention.

The security personnel should be mentally tested during the recruitment process in order to avoid chaos in society. However, the government should prioritize sim-cards registration in the 
country in order to track and trace the kidnapper's ransom negotiation calls and should also equip security personnel with modern technological equipment and essential incentives to allow them to carry out their operation without obstruction. Finally, the government should eradicate illegal possession of firearms and adopt strict policies and public awareness on the impacts of unlawful arms possession and kidnapping in the country. The approach will also reduce Post Traumatic Stress Disorder among community members due to hazardous fear of crime and will enhance concerted police/community vigilante synergy as well as lean the hatred of police in the community.

\section{Conclusion}

The study uncovers that kidnapping in Nigeria has lucratively turn into a multi-million-naira business, and it scrutinizes the phenomenon from its historical context. The study highlighted the fundamental root causes of kidnapping, including endemic corruption, joblessness, lack of capital punishment, and quick-money syndrome. The study went further to elaborate on the jeopardizing threat and the implications kidnapping posed on Nigerian external relations, foreign direct investment, tourism, economic growth, and international reputation. The study suggested that the citizens' protection and development is a moral issue and a key priority of the state and international security. Strategically the study also recommends that the government should, as a matter of urgency, constitute strategic measures such as the implementation of synergized security and community policing approach, a series of employment and empowerment programs, public awareness, and micro-disarmament and mandatory policy of sim registration. Lastly, by implementing such measures, heinous crimes, including kidnapping, will be eradicated and deter a vicious circle of perpetrators in Nigeria for a harmonious and productive society with economic wellbeing and prosperity.

\section{Acknowledgment}

This paper and the research behind it would not have been possible without the exceptional support of Dr. Nasa` I Muhammad Gwadabe and Usman Sufyan Duguri; their enthusiasm, knowledge, and exacting attention to detail have been an inspiration and kept my work on track from my first encounter with research to the final draft of this paper. Finally, it is with true pleasure that the principal author acknowledges the contributions of his parents, Ibrahim Muhammad Nakaduna and Hajara Yarima, who have sacrificed all they have to support him in pursuing the goals and dreams.

\section{Reference}

Adagbabiri, M. M., \& Okolie, U. C. (2018). Corruption and the Challenges of Insecurity in Nigeria's Fourth Republic. Journal of Political Science and Leadership Research, 4(3), 41-56. https://iiardpub.org/get/JPSLR/VOL.\%204\%20NO.\%203\%202018/Corruption\%20a nd\%20the\%20Challenges.pdf

Adeniran, T. (1983). Introduction to international relations. Macmillan.

Ajibola, Yusuff, M. (2016). Performance Assessment of Tourism Sector as a Vital Tool of Economic Growth in Nigeria. International Journal of Academic Research in Business and Social Sciences, 6(10), 143-150. https://doi.org/10.6007/ijarbss/v6$\underline{\mathrm{i} 10 / 2342}$ 
Akinlo, A. E. (2004). Foreign direct investment and growth in Nigeria: An empirical investigation. Journal of Policy Modeling, 26(5), 627-639. https://doi.org/10.1016/j.jpolmod.2004.04.011

Akpan, N. S. (2010). Kidnapping in Nigeria's Niger delta: An exploratory study. Journal of Social Sciences, 24(1), 33-42. https://doi.org/10.1080/09718923.2010.11892834

Akwara, A. F., Biu, I. M., Abutu, G., \& Okwelume, R. (2014). Human Resource Management and Development of the Tourism and Hospitality Industry in Nigeria. Journal of Good Governance and Sustainable Development in Africa, 2(1), 97-105. http://rcmss.com/2014/JGGSDA-VOl2-

No1/Human\%20Resource\%20Management\%20and\%20Development\%20of\%20the \%20Tourism\%20and\%20Hospitality\%20Industry\%20in\%20Nigeria.pdf

Alaibe, T. (2010). Presidential amnesty programme one year after. Champion Newspapers.

Amaza (2020, November 24). Nigeria is also losing control of its troubled northwest region.

Quartz Africa. https://qz.com/africa/1935821/nigeria-losing-control-of-northwestregion-to-bandit-herdsmen/

Anifowose, R. (1982). Violence and politics in Nigeria: The Tiv and Yoruba Experience. Nok Publishers International.

Asiedu, E. (2006). Foeign Direct Investment in Africa: The role of Natural Resources, Market Size, Government Policy, Institution and Political Instability. Department of Economics, University of Kansas, 29(1), 63-77. https://doi.org/10.1111/j.14679701.2006.00758.x

Aziz, H. (2001). The journey: an overview of tourism and travel in the Arab/Islamic context. In Tourism and the less developed world: Issues and case studies. London: CAB International Wallingford, UK.

Badiora, A. I. (2015). Regional differences and developmental implications of security challenges in Nigeria: The case of kidnapping. African Security Review, 24(1), 5562. https://doi.org/10.1080/10246029.2014.990394

Bakare, A. S. (2010). Multinational direct investment and economic growth in Nigeria: An empirical study. International Business Management, 4(3), 171-176. https://doi.org/10.3923/ibm.2010.171.176

Bello, I., Dutse, A. I., \& Othman, M. F. (2017). Comparative analysis of Nigeria foreign policy under Muhammadu Buhari administration 1983-1985 and 2015-2017. Asia Pacific Journal of Education, Arts and Sciences, 4(4), 43-52. https://www.apjeas.apjmr.com

Brucan, S. (1978). UN system and its challenges. Pacific community, 9(3), 302-315.

Christi, I. K. V. P. (2008). Report of the Zones of Peace meeting. Utrecht.

Danlami, B. M. (2012). Analysis of the environmental sustainability of tourism infrastructure development at Yankari game reserve, Bauchi-Nigeria.

Enders, W., Sandler, T., \& Parise, G. F. (1992). An econometric analysis of the impact of terrorism on tourism. Kyklos, 45(4), 531-554. https://doi.org/10.1111/j.14676435.1992.tb02758.x

Etemike, L. (2012). International dimension of the Niger delta crisis: An insight into Nigeria's foreign policy challenges. Journal of Alternative Perspectives in the Social Sciences, $4(3)$, 577-593. https://www.japss.org/upload/2._International_dimension_of_the_niger_delta_crisis . $\mathrm{pdf}$

Felix, J. M., \& Okumoko, T. P. (2014). Combating insecurity in Nigeria: An Integrated Conflict Management Approach. Journal of Empirical Economics, 3(4), 232-238. https://ideas.repec.org/a/rss/jnljee/v3i4p4.html 
Hazen, J. M., \& Horner, J. (2007). Small arms, armed violence, and insecurity in Nigeria: The Niger Delta in perspective ( $\mathrm{p}$. 83). Geneva: Small Arms Survey. http://www.jstor.com/stable/resrep10752.1

Hobden, S. (1999). Theorizing the international system: perspectives from Historical Sociology. Review of International Studies, 257-271.

Hobden, S. and Jones, R.W (1997) World system theory. In Baylis, J and Smith, S. (Eds) The Globalisation of world politics: An introduction to international relations. Oxford University.

Ibrahim, Y. K., \& Ahmad, A. A. (2020). Causes of kidnapping in Nigeria and proposed solutions. The Journal of Social Science Research, 6(5), 512-517. http://dx.doi.org/10.32861/jssr.65.512.517

Ifeoma, O. R., Purity, N. O., \& Anagbogu, T. (2015). Security challenges and the implications for business activities in Nigeria: A critical review. Journal of Policy and Development Studies, 289(1850), http://www.arabianjbmr.com/pdfs/JPDS_VOL_9_2/14.pdf

Ivanovic, M. (2008). Cultural tourism. Juta and Company Ltd.

Ibrahim, Y. K., Ahmad, A. A., \& Duguri, U. S. (2020). The causes of kidnapping and its implications on Nigeria. Liberal Arts and Social Sciences International Journal (LASSIJ), 4(1), 1-9. https://doi.org/10.47264/idea.lassij/4.1.1

Ibrahim, Y. K., Ahmad, A. A., \& Duguri, U. S. (2020). The complexities of South African xenophobia on Nigerian nationals. Liberal Arts and Social Sciences International Journal (LASSIJ), 4(2), 71-83. https://doi.org/10.47264/idea.lassij/4.2.7

Knoema. (2018). World data atlas Nigeria. Knoema. https://knoema.com/atlas/Nigeria/datasets

Knoema. (2019). Total types of violence to crew kidnapping. Knoema https://knoema.com/PARS2018/piracy-and-armed-robbery-againstships?tsId=1007370

Knoema. (2018). Nigeria-Net foreign direct investment inflows in current price. Knoema.

Kum \& Forku, (2020). Cameroon, 11 kidnapped teachers, freed. Anadolu Agency.

Mallett, R., \& Slater, R. (2012). Growth and livelihoods in fragile and conflict-affected situations. London: Working Paper.

Mansur, (2021). Nigerian families await news of 300 kidnapped school girls. AP News. https://apnews.com/article/kidnapping-africa-shootings-west-africa-nigeria$\underline{\text { f15556d816168e14ccd904a19bfaf3bb }}$

Mcloughlin, C. (2012). Topic guide on fragile states. In Birmingham, UK: Governance and Social Development Resource Centre, University of Birmingham.

Muhammad. (2019, 21 April). British woman killed three other kidnapped in Northern Nigeria. https://www.reuters.com/article/us-nigeria-security/british-woman-killed-threeother-people-kidnapped-in-northern-nigeria-idUSKCN1RX0GR

Nwogwugwu, N., Alao, O. E. \&, \& Egwuonwu, C. (2012). Militancy and insecurity in the Niger delta: Impact on the inflow of foreign direct investment to Nigeria. Kuwait Chapter of Arabian Journal of Business and Management Review, 2(1), 23-37. http://arabianjbmr.com/pdfs/KD_VOL_2_1/3.pdf

Nwozar, A. (2010). A delta of a minefield: Oil resource conflict and the politics of amnesty in Nigeria. Conflict Trends, 10(1), 28-35. https://hdl.handle.net/10520/EJC16071

Obarisiagbon, E. ., \& Aderinto, A. . (2018). Kidnapping and the challenges confronting the administration of criminal justice in selected states of Nigeria. African Journal of Criminology \& Justice Studies, 11(1), 41-54. https://www.umes.edu/uploadedFiles/_WEBSITES/AJCJS/Content/VOL\%2011\%2 


\section{OBARISIAGBON\%20FINAL.pdf}

Ojukwu, C. C. (2011). Terrorism, foreign policy, and human rights concerns in Nigeria. Journal of Sustainable Development in Africa, 13(4), 371. https://jsdafrica.com/Jsda/Vol13No4_Summer2011_B/PDF/Terrorism\%20Foreign\%20Policy \%20and\%20Human\%20Rights\%20Concerns\%20in\%20Nigeri1.pdf

Olaniyi. (2020, 2 February). The travel ban, Nigeria, to comply with the US rules. Daily-trust https://www.dailytrust.com.ng/travel-ban-nigeria-to-comply-with-us-visa-rulesgets-cttee.html

Oriakhi, D., \& Osemwengie, P. (2012). The impact of national security on foreign direct investment in Nigeria: An empirical analysis. Journal of Economics and Sustainable Development, 3(13), 88-96. http://pakacademicsearch.com/pdf-files/ech/520/88-96 Vol 3, No 13 (2012).pdf

Pitts, W. J. (1996). Uprising in Chiapas, Mexico: Zapata lives, tourism falters. In Tourism, crime, and international security issues. Wiley.

Pizam, A., \& Mansfeld, Y. (1996). Tourism, crime, and international security issues. Wiley.

Richter, L. K. (1983). Tourism politics and political science: A case of not so benign neglect. Annals of Tourism Research, 10(3), 313-335. https://doi.org/10.1016/01607383(83)90060-9

Richter, L. K., \& Waugh, W. L. (1986). Terrorism and tourism as logical companions. Tourism Management, 7(4), 230-238. https://doi.org/10.1016/0261-5177(86)90033-6

Senge, P. M., Smith, B., Kruschwitz, N., Laur, J., \& Schley, S. (2008). The necessary revolution: How individuals and organizations are working together to create a sustainable world. Crown Business.

Shelley, L. I., \& Melzer, S. A. (2008). The nexus of organized crime and terrorism: Two case studies in cigarette smuggling. International Journal of Comparative and Applied Criminal Justice, 32(1), 43-63. https://doi.org/10.1080/01924036.2008.9678777

Statista. (2020). Direct and contribution of travel and tourism to GDP from 2006 to 2019. Statista. $\quad$ https://www.statista.com/statistics/233223/travel-and-tourism--totaleconomic-contribution-worldwide/

Trading Economics. (2020). Nigerian foreign direct investment 2007 to 2019 data. https://tradingeconomics.com/nigeria/foreign-direct-investment

Tucker, (2020). US citizen kidnapped in Niger rescued in Military operation. AP News https://apnews.com/article/kidnapping-africa-west-africa-nigeria-nigerd2578bfe74dbff88d16475d03a0281f1

Uma, K. E., \& Ikpe, M. (2016). Boko Haram insurgency: Consequences for foreign technology flows in Nigeria. International Journal of Research in Applied, Natural and Social Sciences, 4(2), 49-58. http://oer.funai.edu.ng/wp-content/uploads/2018/05/2-141455780832-6.applied-BOKO-HARAM-INSURGENCY-Kalu-E-Uma.pdf

Utete, C. M. B. (1985). Foreign policy and the developing state. In Ojo et al., (eds) African international relations. Longman.

Wallerstein, I. (1976). A world-system perspective on the social sciences. The British Journal of Sociology, 27(3), 343-352. http://links.jstor.org/sici?sici=00071315\%28197609\%2927\%3A3\%3C343\%3AAWPOTS\%3E2.0.CO\%3B2-8

Wallerstein, I. (1974). Dependence in an interdependent world: The limited possibilities of transformation within the capitalist world economy. African Studies Review, 1-26. http://www.jstor.org/stable/523574 n 